\author{
Mariusz Korzeniowski \\ Uniwersytet Marii Curie-Skłodowskiej w Lublinie (Polska) \\ Maria Curie Skłodowska University in Lublin (Poland) \\ e-mail:marius@poczta.umcs.lublin.pl
}

https://orcid.org/0000-0001-9245-3987

\title{
Białoruś i jej mieszkańcy w latach I wojny światowej w świetle wspomnień
}

Belarus and its inhabitants during the First World War in the light of memoirs

Беларусь і яе насельніитва ў перыяд першай сусветнай вайны у святле ўспамінаў

\begin{abstract}
During the First World War, Belarus and its inhabitants became a recurrent subject in memories and memoirs alike. The observations and attempts at the assessment of events in the nearer and further perspective undertaken on an ongoing basis since the end of the Great War are of various cognitive value. It is worth noting that their authors originated not only from the local population, but could also be newcomers from the Polish lands. For the latter, the clash with Belarusian reality and society constituted an opportunity for a number of observations, including those concerning various aspects of human existence, mentality, culture and work. The reflections contained in this article, based on subjectively selected memoirs, constitute an attempt to present the conclusions of the authors of said memoirs regarding the attitudes of the residents of Belarusian governorates, the national consciousness of Belarusians, or several aspects of their political activity during the First World War. These observations have high cognitive value, as they define the distinctive traits of the local population, and assess their behavior during the war. The study also shows that Belarus and its inhabitants did not constitute a significant issue for the authors of the memoirs analyzed. The evolution of the Belarusian national movement was discussed therein only occasionally.
\end{abstract}

Keywords: Belarusians, First World War, memoirs, national consciousness, Belarusian national movement 


\begin{abstract}
Abstrakt
Białoruś i jej mieszkańcy w latach I wojny światowej stali się jednym z tematów wypełniających wspomnienia i pamiętniki. Obserwacje, podejmowane - w bliższej lub dalszej perspektywie od zakończenia Wielkiej Wojny - próby oceny zachodzących zdarzeń posiadają różny walor poznawczy. Warto zwrócić uwagę, że ich autorzy wywodzili się nie tylko z ludności miejscowej, ale także przybywali z ziem polskich. Dla tych ostatnich zetknięcie się z białoruską rzeczywistością i społeczeństwem niosło możliwość dokonania szeregu obserwacji, m.in. dotyczących: różnych aspektów ludzkiej egzystencji, mentalności, kultury czy pracy. Przedmiotem rozważań, prowadzonych na podstawie subiektywnie dobranych wspomnień, będzie próba przedstawienia dokonanych przez ich autorów obserwacji, a więc oceny postaw mieszkańców guberni białoruskich, świadomości narodowej Białorusinów czy postrzeganie niektórych aspektów ich działalności politycznej w latach I wojny światowej. Poczynione obserwacje mają ważny walor poznawczy. Pozwalają zapoznać się z charakterystyką miejscowej ludności, a zarazem ich oceną formułowaną w latach I wojny światowej.
\end{abstract}

Słowa kluczowe: historia Białorusi, Białorusini, I wojna światowa, wspomnienia

\title{
Анатацыя
}

Беларусь і яе насельніцтва ў перыяд першай сусветнай вайны сталіса адной з папулярных тэм тагачасных успамінаў і дзённікаў. Назіранні, спробы непасрэднай ацэнкі здарэнняў, што адбываліся адразу пасля вялікай вайны ці трохі пазней, характарызуюцца розным пазнавальным узроўнем. Варта звярнуць увагу на тое, што іх аўтарамі былі не толькі выхадцы з аўтахтоннага насельніцтва, але таксама і прышэльцы з польскіх земляў. Для польскіх бежанцаў сутыкненне з беларускай рэальнасцю і мясцовым насельніцтвам давала магчымасць назнаёміцца 3 рознымі аспектамі чалавечага жыцця, ментальнасці, культуры і дзейнасці. Прадметам даследавання, якое абапіраецца на матэрыяле суб'ектыўна выбраных аўтарам успамінаў, з'яўляецца спроба прадстаўлення назіранняў сведкаў, то бок ацэнкі пункту погляду жыхароў беларускіх губерняў, нацыянальнай свядомасці беларусаў, успрымання некаторых аспектаў іх палітычнай дзейнасці ў перыяд першай сусветнай вайны. 3 разваг паўстае карціна, з якой вынікае, што Беларусь і яе жыхары не былі непасрэдным прадметам зацікаўлення аўтараў успамінаў. Нягледзячы на гэта назіранні сведкаў і так прыносяць каштоўную інфармацыю. Дазваляюць пазнаёміцца 3 характарыстыкай аўтахтоннага насельніцтва i іх ацэнкай, з якой вынікае, што частка аўтараў успамінаў не разумее палітычных імкненняў беларусаў у так істотным для іх гісторыі перыядзе, якім з'яўляліся гады першай сусветнай вайны.

Ключавыя словы: гісторыя Беларусі, беларусы, першая сусветная вайна, успаміны 
dziejach Białorusi i jej mieszkańców I wojna światowa odegrała szczególną rolę. Ziemie białoruskie stały się bowiem obszarem, na którym toczyły się działania wojenne. Po ustabilizowaniu się jesienią 1915 r. linii frontu niemiecko-rosyjskiego doświadczyły skutków stacjonowania wojsk walczących stron. W letnio-jesiennych miesiącach 1915 r. mieszkańcy tych ziem odczuli następstwa przymusowego przemieszczania się w głąb Rosji uchodźców z ziem polskich, a także z tych terytoriów białoruskich, które zostały objęte operacjami militarnymi. Dodajmy, że ziemie białoruskie nieokupowane przez wojska niemieckie stały się miejscem tymczasowego pobytu setek tysięcy wygnańców. W latach 1917-1918 przebiegały przez nie główne szlaki powrotu z Rosji ludności polskiej (zwłaszcza uchodźców), a także reprezentantów innych narodowości (w tym Białorusinów).

Białorusi nie ominęły również brzemienne w skutkach, wynikające $\mathrm{z}$ rewolucji lutowej i przejęcia władzy w Rosji przez maksymalistów, zdarzenia wywołane zmianą ustroju, a zwłaszcza wypadki związane z rozprzężeniem w armii rosyjskiej, wzrastającą anarchią i radykalizacją postaw ludności. Udziałem rdzennych mieszkańców tych ziem stały się także dążenia emancypacyjne zwieńczone ogłoszeniem 25 marca 1918 r. niepodległości przez Białoruską Republikę Ludową.

Białoruś i jej mieszkańcy stali się jednym z tematów poruszanych we wspomnieniach $^{1}$ przedstawicieli polskiego ziemiaństwa stale mieszkającego na tych terenach (np. Edward Woyniłłowicz, Maria Czapska) lub tymczasowo przebywających na ziemiach białoruskich (np. Władysław Glinka, Michał Stanisław Korwin-Kossakowski). Spisane obserwacje, podejmowane na bieżąco próby oceny zdarzeń bądź wrażenia zanotowane po zakończeniu Wielkiej Wojny posiadają różny walor poznawczy. W przypadku przybyszów zetknięcie się z białoruską rzeczywistością stawało się okazją do sporządzenia wpisów dotyczących różnych aspektów ludzkiej egzystencji, mentalności, kultury czy pracy. Należy podkreślić, że cechą wspólną osób podejmujących trud pisania wspomnień jest ich polskie pochodzenie. Dla części autorów kilkuletnie „doświadczenie Białorusi” stanowiło konsekwencję przymusowego opuszczenia rodzinnych stron, znajdujących się w Królestwie Polskim czy też na Litwie. Dlatego też celem rozważań, prowadzonych na podstawie subiektywnie dobranych wspomnień, będzie próba omówienia dokonanych przez nich zapisów, zawierających m.in. ocenę postaw mieszkańców guberni białoruskich, ich świadomości narodowej czy rozwoju działalności politycznej na omawianym terytorium w latach I wojny światowej.

Wśród notatek Michała Stanisława Korwin-Kossakowskiego (w tym czasie naczelnika 82. Oddziału Sanitarnego Rosyjskiego Towarzystwa Czerwonego Krzyża), sporządzonych po przekroczeniu Bugu i przejechaniu przez Brześć Litewski, znajdują się opisy pokazujące, w jaki sposób cofające się oddziały rosyjskie zmuszały miejscową ludność do opuszczania rodzinnych stron. Zapiski te pokazują, że doświadczyła ona, podobnie jak w guberniach polskich, niszczycielskiego impetu cofających się

W niniejszej pracy stosuję termin wspomnienia, którym obejmuję dzienniki i pamiętniki sporządzone przez autorów przebywających w guberniach białoruskich w latach I wojny światowej. 
Rosjan. W takiej sytuacji znaleźli się na przykład mieszkańcy Andronowa, których wypędzili Kozacy, mający rozkaz podpalenia wsi (Kossakowski, 2010, s. 268). Ludzie uciekali w okolicznościach pełnych dramatyzmu, dzieląc tym samym los Królewiaków, co nader trafnie ujął Korwin-Kossakowski, pisząc:

Dramat wisi w powietrzu: na polach pusto, a w wioskach wre, jak w trąconym stopą ludzką mrowisku. Ludność przerzuca się z kąta w kąt, miota się w panice, snadź ludzie nie spodziewali się doczekać huku i trzasków strzałów szybko zbliżających się teraz do ich wiosek (2010, s. 272).

W pełni zasadna stała się zatem refleksja autora diariusza, że „okrutną, a niezasłużoną krzywdę czyni się temu krajowi i tym biednym ludziom! Licha, idiotycznie przeprowadzona karykatura 1812 roku!" (Kossakowski, 2010, s. 269).

Władysław Glinka, właściciel Suska Starego w Ostrołęckiem, sam uchodźca, nieco inaczej jednak ujmował status migrującej na wschód ludności białoruskiej. Na początku września 1915 r., przemieszczając się na szlaku migracyjnym, po opuszczeniu Snowa-Dolnego odnotował we wspomnieniach, że mijał ,już samych Białorusinów, którzy - jak twierdził - byli nie wygnańcami, a istotnie zbiegami czy uciekinierami, albowiem na 100 wiorst, a nawet dalej od linii boju, uciekali w świat" (Glinka, 1927, t. 1, s. 133).

O zasilaniu płynącej z Kongresówki fali uchodźczej rzeszami Białorusinów pisał z kolei Stanisław Wojciechowski (prezydent II Rzeczypospolitej). Jednocześnie wyraził zdziwienie postawą prawosławnego duchowieństwa, które zamiast powstrzymywać wiernych przed wyjazdem z rodzinnych domów, jako pierwsze je opuszczało, a tym samym pociągało za sobą parafian (Wojciechowski, 1938, s. 238). Autor pamiętnika nader krytycznie wyrażał się o nieprzestrzeganiu przez białoruskich uciekinierów elementarnych zasad higieny, co doprowadziło do licznych wśród nich ofiar śmiertelnych, spowodowanych wybuchem epidemii cholery (Wojciechowski, 1938, s. 238-239).

Warto zauważyć, że Glinka skupiał się nie tylko na opisie położenia swojej rodziny i ewakuowanego majątku, ale także przedstawiał sytuację uchodźców spotkanych na szlaku migracyjnym. W zapisach pamiętnikarskich znalazły się też refleksje poświęcone mijanym miasteczkom i wsiom. Korzystne wrażenie, w przeciwieństwie do Prużany, wywarł na Glince Słonim. O ile pierwsze zapamiętał jako nad wyraz brudne, zamieszkane głównie przez Żydów, nazywając jednak „ożywionym i wesołym miasteczkiem”, o tyle widok Słonima wywarł na nim korzystne wrażenie. Pamiętnikarz zapamiętał Słonim jako miasto duże, „ładnie położone na wzgórzach”, posiadające dobrze zaopatrzone sklepy. Nie ulega wątpliwości, że wpływ na tak pozytywną ocenę wywarły znajdujące się w mieście, napawające „dumą niezatarte, dostojne ślady polskiej kultury”. Glinka nie omieszkał zauważyć, że trzy słonimskie kościoły „po barbarzyńsku przerobiono na cerkwie, ale mnóstwo domów prywatnych rzuca się w oczy strukturą i ornamentacją renesansową" (Glinka, 1927, t. 1, s. 99, 117-118). Przywołany przykład, jak również inne rozwiązania architektoniczne w mieście, oraz 
widok podobnych budowli w Prużanie i Różanie posłużyły do sformułowania opinii, że potężne „tchnienie zachodniego Odrodzenia, przez nas tu przed wiekami przyniesione, nie dało się dotąd jeszcze przytłumić moskiewskiej i żydowskiej przemocy i deprawacji" (Glinka, 1927, t. 1, s. 118).

Dużym zaskoczeniem dla autora wspomnień okazał się wygląd Mińska. Jak sam przyznał, wyobrażał sobie stolicę ziem białoruskich ,jako marną żydowsko-rosyjską mieścinę". Tymczasem miasto wzbudziło jego uznanie rozległością, liczbą ulic z solidną zabudową, kursującymi po nich konnymi tramwajami oraz oświetleniem elektrycznym. Glinka posunął się wręcz do stwierdzenia, że było to miasto europejskie, „,z którym mało z naszych miast prowincjonalnych równać się może”. Mińsk tętnił życiem, zachwycał bogatymi, dobrze zaopatrzonymi sklepami. Autor pamiętnika skwapliwie odnotował, że na „ulicach, w sklepach, hotelach, wszędzie mowa polska i napisy często, obok rosyjskich, polskie" (Glinka, 1927, t. 1, s. 143).

Korzystne na ogół wrażenie na autorach wspomnień robiły, jak się przyjmuje, również inne miasta białoruskie. Eugeniusz Ignacy Romer (ziemianin, działacz społeczny i polonijny na Litwie) w dość lapidarnym opisie zaznaczył, że w Połocku prezentowały się nad wyraz okazale, widoczne z daleka: cerkiew i klasztor św. Eufrozyny, a także przekształcone w cerkwie dawne kościoły (pojezuicki i dominikański) oraz czynna świątynia katolicka (Romer, 1995, s. 318).

W tonie zadumy pisał o Nieświeżu Ryszard Marian Wójtowicz (instruktor Centralnego Komitetu Obywatelskiego guberni Królestwa Polskiego w Rosji). Podobnie jak niektórzy autorzy wspomnień poczynił uwagę, że miejscowe zabytki świadczyły o przynależności ziem białoruskich do Rzeczypospolitej szlacheckiej, a nieświeski „pałac, brama, kościółek, cerkiew przerobiona z kościoła” miały przypominać okres jej świetności:

Patrząc na tę siedzibę książąt, magnatów litewskich [tj. Radziwiłłów - M.K.] - konstatował dalej Wójtowicz - ma się wiarę i ufność, że to wszystko jakby śpi w letargu, czekając rozkazu przebudzenia, jak ci rycerze Chrobrego. Wierzy się, iż tu kiedyś grzmieć będzie chwała polskiego imienia (Wójtowicz, 1936, s. 24).

Przedmiotem pamiętnikarskich zapisów stała się również białoruska wieś. Wartość analizowanych zapisów niewątpliwie podnosi fakt znajomości wiejskich realiów, jaką posiadali ziemianie, na co dzień stykający się z włościanami (np. Glinka, Korwin-Kossakowski). Glinka, opisując przymusową migrację na wschód, zanotował w memuarach, że - począwszy od Słonima - widział „we wsiach typowe dachy, na 4 strony słomą kryte, z podwójnym okapem u obu szczytów. Wsie, bardzo zresztą rzadko rozrzucone, czynią wrażenie zamożnych" (Glinka, 1927, t. 1, s. 133-134).

Uwaga ta stoi w sprzeczności z opisami białoruskiej wsi sporządzonymi przez Wójtowicza. Dokonując objazdu rozmieszczonych na prowincji partii uchodźców z Królestwa Polskiego, pisał on, że spotykał wśród „lasów [...] wioski brudne, z izbami wykrzywionymi, z ulicami tak pełnymi błota, że koła wpadają do [po? - M.K.] 
osie” (Wójtowicz, 1936, s. 41). Dopełnienie tego obrazu stanowiły „cerkwie biedne, cmentarze, śmietniki nieogrodzone, pełne uschniętych liści, połamanych gałęzi, wywróconych krzyżów, nierogacizna ryje rozsypane i zapadłe w ziemię mogiły" (Wójtowicz, 1936, s. 41). Piszący krytycznie wypowiadał się również o rolniczych umiejętnościach miejscowego chłopstwa, które według Wójtowicza gospodarowało nader prymitywnie, nie mając pojęcia o stosowaniu sztucznych nawozów czy wykorzystaniu maszyn rolniczych (np. młocarni parowych) (Wójtowicz, 1936, s. 40).

Kontrastującą z jego spostrzeżeniem opinię sformułowała Helena Obiezierska (ziemianka, doktor nauk humanistycznych, nauczycielka języka polskiego). Zauważając różnice między chłopami białoruskimi a rosyjskimi, zanotowała w pamiętniku, że jej zdaniem białoruscy włościanie z otwartością śledzili wprowadzane w majątkach ziemskich innowacje i „z chęcią je” naśladowali. W przeciwieństwie do nich chłopów rosyjskich cechowały nieufność i podejrzliwość w stosunku do podejmowanych przez ziemiaństwo prób zmierzających do podniesienia kultury rolnej, co przejawiało się w niszczeniu maszyn czy zasiewów nowych gatunków zbóż (Obiezierska, 1995, s. 76).

Warto zaznaczyć, że Wójtowicz nie szczędził też krytycznych ocen napotkanym dworom, które „mało zwracają uwagę na uprawę roli; cały dochód czerpią z wyrębów lasu oraz gorzelni” (Wójtowicz, 1936, s. 41). Informację tę należy traktować raczej jako odosobnione subiektywne spostrzeżenie, niewątpliwie jednak oddające stan odwiedzanych przez pamiętnikarza majątków ziemskich. Lektura chociażby wspomnień Glinki, Antoniego Kieniewicza (ziemianina, ojca wybitnego polskiego historyka Stefana Kieniewicza) czy Obiezierskiej pozwala bowiem stwierdzić, że istniały dobrze zorganizowane dobra ziemskie, specjalizujące się w uprawach czy hodowli inwentarza żywego (Glinka, 1927, t. 1, s. 151; Obiezierska, 1995, s. 22, 79; Kieniewicz, 1989, s. 215-223).

Nie mniejszą uwagę autorzy wspomnień poświęcili miejscowej ludności. Krytyczną opinię wyraził Glinka, który - przypatrując się białoruskim chłopom w Mińsku, a jednocześnie porównując ich do rosyjskich - zanotował:

[...] te tłumy Białorusów i Białorusek czyniły wrażenie odrażające; każde niosło paczki rubli do kasy, a wyglądali jak żebracy, obdarci, cuchnący, wyraz ich twarzy był zły, ponury, dziki. Tutaj brud taki sam, odzież z łachmanów plugawych, obuwie, tu jak i tam [autor ma na myśli chłopów rosyjskich spotkanych w Rosławlu - M.K.], ze szmat i łyka, lecz wyraz twarzy zupełnie inny: obojętny, bezmyślny, lecz pogodny, dobroduszny. U tamtych pojedyncze rysy twarzy nieraz delikatne, lecz jakby wytrącone z normalnego położenia, pokrzywione, typ nie tak ordynarny, jak brzydki; u tych rysy regularne, ale grube, jakby toporem wyciosane, całość nade wszystko wulgarna. To samo dotyczy mężczyzn i kobiet (1927, t. 2, s. 98).

Wójtowicz z kolei portretował lud białoruski jako „obraz wiecznej niedoli; wiecznie zalękniony, znękany, uniżony (kłania się przejeżdżającym, zamiast naszego «Niech będzie pochwalony»)" (1936, s. 21). W dalszej części wspomnień charakteryzował miejscowych chłopów jako grupę zapomnianą przez Boga, najbardziej nieszczęśliwą i wydziedziczoną. Białorusin według Wójtowicza to także „doskonały typ niewolnika: 
nadzwyczajna pokora, związana z brakiem poszanowania, lękliwość, uniżona czołobitność, zupełny brak wiary w siebie, w swoje zdolności, pracę" (1936, s. 24). Należy jednak oddać autorowi pamiętnika, że przyczyn ukształtowania zniewolonej postawy miejscowej ludności dopatrywał się w tym, „co panowie polscy zaczęli, to rząd rosyjski dokończył: ostatecznie ogłupił nieszczęsny lud" (Wójtowicz, 1936, s. 24).

Charakterystykę białoruskiego chłopa dopełnia w pewnym stopniu spostrzeżenie Romera, który konkludował, że byli oni wprawdzie ciemni, biedni i nieufni, ale nie dopatrzył się w nich chytrości i niechęci wobec ziemian, choć dodawał, że „racji do wielkiej życzliwości dla dworu nie ma, więc trudno się tego uczucia spodziewać" (1995, s. 552).

Trafna konkluzja memuarysty nie w pełni współbrzmiała z opiniami o harmonii między mieszkańcami dworów i ich włościańskimi sąsiadami. O dobrych relacjach między ziemiaństwem i okolicznym chłopstwem pisała bowiem Obiezierska. Jako przykłady podała pomoc udzieloną przez mieszkańców wsi Korolewicze przy zwózce budulca i budowie obory w majątku Turów, uczestniczenie mieszkańców Sukremna we wznoszeniu czworaków oraz domu mieszkalnego czy przygotowywaniu ziemi pod uprawę w dobrach Krucza. Dodajmy, że pomoc ze strony chłopów okazana właścicielce Krucza Żenie Wołłowiczowej miała być podyktowana współczuciem włościan z powodu kalectwa jej męża (Obiezierska, 1995, s. 73-74).

O dobrych relacjach między ziemianami a wiejskimi sąsiadami, wspieraniu rodzin powołanych do wojska chłopów pisał również właściciel Dereszewicz Kieniewicz (1989, s. 427, 457). Obraz wzajemnych, pełnych harmonii i zgody, stosunków, a tym samym pozytywnego wizerunku chłopskiego sąsiada, okazał się ułudą. Wizja ta uległa zmianie w czasach narastania napięcia i polaryzacji nastrojów społecznych po obaleniu caratu, a następnie po przejęciu władzy przez bolszewików. Trudno oprzeć się wrażeniu, że rodziny ziemiańskie były zaskoczone radykalizacją postaw włościańskich sąsiadów. Tak można odebrać wywód Edwarda Woyniłłowicza (ziemianina, działacza społecznego i gospodarczego) czy Kieniewicza, który pisał:

Rozgromienie zostało dokonane nie przez żywioły obce, nie przez wałęsające się żołdactwo, lecz przez ludność najbliższej wsi Hołubicy. Ludność wsi, z którą żyli w największej zgodzie i harmonii moi dziadostwo, następnie moi rodzice, a potem my oboje. Wsi, w której znaliśmy po imieniu nie tylko każdego gospodarza, lecz jego żonę i dzieci, [...]. Wsi, która wydawała w ciągu długich lat szereg uczciwych, porządnych, wiernych i oddanych służbistów w postaci stałych pracowników [...]. Wsi, która za pracę we dworze otrzymywała tygodniowo setek rubli; wsi, do której na każde zawołanie do ciężko chorego mężczyzny, kobiety lub dziecka przyjeżdżał dworski doktor lub felczer [...]. I to ta wieś najbliższa, ta swoja mogła dokonywać tak okropnego czynu! (1989, s. 457).

Powodów zmiany postawy, a co za tym idzie udziału w pogromie majątku Sawicze, części włościańskich sąsiadów Woyniłłowicz dopatrywał się w polityce caratu, który od momentu dokonania rozbioru Rzeczypospolitej przez swoich urzędników, 
cerkiew prawosławną czy przez „,szereg ustaw prawodawczych i plan reform agrarnych, w sądzie, w gminie i szkole" nieustannie pracował nad tym, ,aby wioskę ze dworem poróżnić i waśń klasowo-narodowościową wzniecić" (Woyniłłowicz, 1931, s. 205-206).

Niezbyt dobrą opinią cieszyli się również białoruscy uciekinierzy. Autorzy, którymi byli miejscowi ziemianie i rosyjscy oficerowie, z uznaniem podkreślali różnice między ludem polskim i białoruskim. Otóż mieli być zachwyceni

[...] uczciwym i delikatnym zachowaniem się naszych wygnańców, w porównaniu z Białorusinami: ci ostatni korzystają z każdej sposobności, aby rabować doszczętnie folwarki i dwory, które w swej ucieczce spotykają. Czego nie mogą wziąc ze sobą, niszczą. Podobno istne to hordy dzikich Hunnów (Glinka, 1927, t. 1, s. 149).

Wydaje się jednak, że postawa ta nie była charakterystyczna li tylko dla uchodzącej ludności białoruskiej. Woyniłłowicz zanotował we wspomnieniach, że uchodźcy z Królestwa Polskiego nie tylko niszczyli „nasze łany”, ale także mieli siać

[...] trwogę i spustoszenie. Nie mogę przesądzać o kraju całym, - pisał dalej - ale w mojej okolicy spustoszenia czynione przez uciekinierów były daleko dotkliwsze i postępowanie ich daleko więcej demoralizowało ludność miejscową [białoruską - M.K.], niż zachowanie się cofających się wojsk (1931, s. 185).

Stwierdzał ponadto, że wycofujące się oddziały armii rosyjskiej nie dokonywały zniszczeń (sic!) bez potrzeby, natomiast uchodźcy wręcz z satysfakcją mieli przejeżdżać przez niezżęte pola, czyniąc to ze świadomością zupełnej bezkarności i jednocześnie „odpowiadając na wszelkie rekryminacje: «my nie tyle straciliśmy»” (Woyniłłowicz, 1931, s. 185). Dlatego też dwory i folwarki drżały na widok zbliżającej się fali uchodźczej, która zatrzymywała się „tam, gdzie jeszcze cokolwiek dla żeru było, jak szarańcza, pozostawiała za sobą pustynię" (Woyniłłowicz, 1931, s. 185).

Zajmującą kwestią jest także zdefiniowanie przez autorów wspomnień stopnia świadomości narodowej etnicznych mieszkańców ziem białoruskich. Obiezierska, opisując stosunek Litwinów i Białorusinów do polskości, poczyniła uwagę, że lud białoruski „nie czuł się polskim, ale również nie poczuwał się do żadnej innej narodowości" (1995, s. 76). Glinka z kolei (zapis z grudnia 1917 r.) nie tylko twierdził, że miejscowy lud nie był polski, ,ale również nie jest rosyjski, ani też białoruski: jest to zero, a jeśli ma jakie duchowe inklinacje, to raczej w naszą stronę niż w rosyjską" (1927, t. 3, s. 180). Konstatacja ta stanowiła kontynuację jego wcześniejszych rozważań, które poprzedził pytaniem „Czyż ten nieszczęsny, dziki lud białoruski, tak starannie w nieprzeniknionej ciemnocie trzymany przez rząd rosyjski, można uważać za duchowego pana tej ziemi?”. Odpowiadając, wyraził wyżej wspomnianą konkluzję, że nie był ludem ani polskim, ani rosyjskim. Jednoznacznie też stwierdzał, że nie tylko nigdy nie posiadał własnej państwowości czy kultury, ale także „o nich nigdy 
nie zamarzył nawet”. Lud białoruski stanowić miał czystą tablicę, „,na której nikt pisać jeszcze nie zaczął" (Glinka, 1927, t. 2, s. 68).

Przemyślenia Glinki w pewnym sensie pokrywają się ze wspomnieniami Obiezierskiej. Stwierdziła w nich, że Białorusini nie okazywali poważania Rosjanom, których nazywali Moskalami; natomiast odnosili się z szacunkiem „do wszystkiego, co polskie [...] jako do czegoś wyższego i «delikatniejszego»". Przekonywać o tym miało również uczestniczenie prawosławnych Białorusinów w nabożeństwach katolickich. Obiezierska wskazywała ponadto, że wśród ludzi przybywających do Sienna na wschodniej Białorusi na uroczystości Bożego Ciała bądź na odpust w dniu patrona kościoła, tj. św. Fortunata, ożywało wspomnienie, że byli kiedyś unitami oraz funkcjonowało przekonanie, że „nabożeństwo katolickie jest o wiele piękniejsze od tego, jakim raczyli ich w cerkwi miejscowi popi, ogólnie przez nich pogardzani” (Obiezierska, 1995, s. 76).

Wspomnienia, szczególnie autorów związanych z ziemiami białoruskimi, zawierają niezmiernie interesujące spostrzeżenia dotyczące genezy i pochodzenia narodowościowego miejscowej szlachty. Woyniłłowicz wręcz stwierdzał, że poważną część ziemiaństwa polskiego na Białorusi, do której zaliczał ziemie znajdujące się w administracyjnych granicach guberni wileńskiej (część), grodzieńskiej (większość) oraz mińskiej, mohylewskiej i witebskiej (całość), „stanowią autochtoni, szlachta miejscowego pochodzenia, niegdyś wyznająca obrządek wschodni, lecz na ogół w XVII wieku już katolicka i spolszczona" (1931, s. 210). Ziemiaństwo miejscowe miało się poczuwać do ,,wspólności krwi z miejscowym ludem”, znało język białoruski oraz lokalne obyczaje i bynajmniej nie dążyło do jego spolszczenia. Wprost przeciwnie - wspierało, ujawniające się w drugiej połowie XIX stulecia, jego aspiracje narodowościowe, których pionierami byli ziemianie polscy (np. Jan Czeczott, Władysław Syrokomla) (Woyniłłowicz, 1931, s. 210).

W podobnym duchu wypowiadała się również Maria Czapska (ziemianka, pisarka, krytyk literacki, siostra Józefa, autora Na nieludzkiej ziemi). W nader lapidarnej formie stwierdzała, że sąsiedzi, należący do ziemiaństwa i mińskiej inteligencji, „wyrośli z białoruskiego pnia". Z pewnego rodzaju przyganą wypominała, wymienionym w pamiętniku np. Woyniłłowiczom, Wańkowiczom, Bogdanowiczom czy Fedorowiczom, że wzbogaceni i nobilitowani

[...] włączali się stopniowo do napływowego elementu polskiego, przyjmując język, obyczaj i wyznanie kolonizatorów, bogacąc swymi znamiennymi walorami tężyzny i bitności element polski, zamiast tworzyć elitę swego narodu (sic!) (Czapska, 2004, s. 272).

Zarzucała tym samym miejscowej elicie, że jej polonizacja była szkodliwa oraz doprowadziła ją do oderwania się od ludu białoruskiego (Czapska, 2004, s. 272). $\mathrm{W}$ pewnym sensie powątpiewanie $\mathrm{w}$ twierdzenie miejscowych ziemian, iż są $\mathrm{z}$,pochodzenia i krwi białoruskiej", a tym samym, że byli Białorusinami, wyraził także Glinka. Zauważył bowiem, odwołując się do przykładu Woyniłłowicza, że działali 
„jak Polacy”; jednocześnie uznawał ich za ,żywioł zakorzeniony i kulturalny, rozwojowy”, konstatując, że „w jednej Polsce, w jej wpływie i kulturze znaleźć może zbawienie kraj ten [Białoruś - M.K.] i barbarzyńska ludność jego" (Glinka, 1927, t. 2, s. 68-69). Dodajmy, że Glinka posunął się nawet do konkluzji, iż postęp i rozwój cywilizacyjny ziem białoruskich, pomimo jego hamowania przez władze rosyjskie, był efektem polskich działań, które powinny rozproszyć „mroki, w których żyje ten lud, [ale - M. K.] i uczynić go polskim" (1927, t. 2, s. 68-69).

O przywiązaniu miejscowej szlachty do polskości w pewnym stopniu może przekonywać notatka Wójtowicza. Stwierdzał w niej, iż „szlachcic ze wsi”, mając na myśli niezamożną szlachtę zagrodową, posługiwał się wprawdzie słabo językiem polskim czy go wręcz nie rozumiał, ale znał w tej mowie, wyniesioną z Kościoła katolickiego modlitwę, której nauczył się od przodków, co tym samym uchroniło go od zerwania związków z polskością. W stosownym momencie, a więc kiedy w latach I wojny światowej nastąpiło ożywienie narodowej pracy polskiej na ziemiach białoruskich, pozwoliło to przedstawicielom szlachty na złożenie deklaracji: jestem Polakiem i „choć mówić nie umiem po polsku, czuję po polsku" (Wójtowicz, 1936, s. 48).

Odrębną kwestię, zajmującą uwagę memuarystów, stanowił stosunek do działalności narodowego ruchu białoruskiego. Niezmiernie intersujące jest nie tyle odnotowywanie kolejnego zjazdu czy też wydarzeń świadczących o aspiracjach narodowych Białorusinów. Lektura pamiętnika Glinki pozwala w tej materii suponować, że dla autora zapisów ich aktywność narodowa była zaskoczeniem, co świadczy o jego nader skromnej wiedzy (wręcz o ignorancji) na temat stosunków narodowościowych i politycznych panujących na Białorusi. Tak bowiem należy odebrać wywód Glinki, w którym pada stwierdzenie, że język białoruski funkcjonował jedynie jako gwara ludowa. Zdziwienie autora wywołała informacja, jaką uzyskał od Zofii Narutowiczówny, że jeszcze przed I wojną światową wydawano w tym języku gazety i książki ,nie bez wartości literackiej" (Glinka, 1927, t. 2, s. 93).

Wartość poznawczą posiada też podana przez Glinkę informacja, że pod okupacją niemiecką Białorusini w Wilnie wydawali, wrogo usposobione do Polaków, ale podkreślające związek białoruszczyzny z kulturą zachodnią, pismo „Homan”. Pamiętnikarz ponadto odnotował powstanie w Grodnie szkoły białoruskiej dla dziewcząt oraz zezwolenie przez Niemców na używanie białoruskiego jako języka wykładowego w przypadku nauczania dzieci, „dla których jest to język domowy” (Glinka, 1927, t. 2, s. 93).

Rozwój białoruskiego ruchu narodowego zarówno przed I wojną światową, jak i w jej trakcie zaskoczył miejscowych działaczy społecznych i politycznych. Wydaje się, że nie zdawali sobie oni jednak sprawy, jak pisała Czapska, z odrębności Białorusi i ,już skrystalizowanego narodowego uświadomienia” (2004, s. 272). Uwagę zwraca utożsamianie przez Woyniłłowicza ruchu narodowego z inicjatywą lokalnego ziemiaństwa (tzw. krajowców) oraz zorganizowaną przy jego współudziale na ostatnich posiedzeniach ziemstwa mińskiego w 1917 r. Przewodnią myślą uczestników ruchu miało być: 
[...] rozbudzenie samopoczucia narodowościowego u Białorusinów, aby wyodrębnić ich od Moskwy i uwolnić spokojny, zdrowy w pojęciach swoich lud białoruski od anarchii, która już wówczas w rdzennej Rosji, coraz to głębsze korzenie zapuszczała (Woyniłłowicz, 1931, s. 210-212).

O słabnącym z czasem zaangażowaniu w białoruski ruch narodowy lokalnych ziemian zadecydował wzrost wpływów socjalistycznych, co tym samym, jak przekonywał Woyniłłowicz, prowadziło do popierania „rządów Kiereńskiego” (1931, s. 212). Dla rozwoju instytucji narodowych niezbędne były środki, których nie mogło zapewnić społeczeństwo białoruskie ,składające się z elementów mało narodowościowo uświadomionych i na ogół niezamożnych”. Dlatego też doszło, jak dowodził pamiętnikarz, do podporządkowania białoruskiego ruchu narodowego Rosji, która dysponowała pieniędzmi i patronowała wszelkiej działalności wywrotowej, ale pod warunkiem podporządkowania się dyrektywom władz (Woyniłłowicz, 1931, s. 212-213).

Glinka odnotował w połowie czerwca 1917 r., że ruch białoruski był wewnętrznie skłócony, o czym miały świadczyć dwa niezależne, wrogie sobie zjazdy przedstawicieli organizacji i partii białoruskich. Członkowie Białoruskiego Komitetu Narodowego, wybrani podczas odbywającego się w kwietniu 1917 r. zjazdu w Mińsku, opowiedzieli się za funkcjonowaniem Białorusi (autonomicznej narodowo i kulturowo) w granicach federacyjno-demokratycznej Rosji. Pierwszy Zjazd Delegatów Chłopskich ${ }^{2}$ wypowiedział się przeciwko narodowej autonomii Białorusi, „,która kulturalnie i narodowo jest i pozostać musi nierozerwalną częścią Rosji” (Glinka, 1927, t. 2, s. 245). Przyczyn braku konsolidacji ruchu i odmiennego stanowiska wobec statusu Białorusi Glinka dopatrywał się w tym, że za ideą „,separatystyczną jest inteligencja pochodzenia białoruskiego, a ciemne włościaństwo" pod wpływem duchowieństwa prawosławnego i z powodów agrarnych opowiadało się za Rosją (Glinka, 1927, t. 2, s. 245).

Romer, zajmując się kwestią przyłączenia Białorusi do Ukrainy, wskazał nie tylko na rozbieżności postaw wśród uczestników zjazdu reprezentujących gubernie witebską, mohylewską i mińską ${ }^{3}$ ale także przedstawił powody, które skłoniły jego uczestników do opowiedzenia się za Rosją. Nie chodziło o przekonanie, że „czuli się bliższymi do Małorosjan niż do Wielkorosjan, ale dlatego, że imponuje im organizacyjność i świadomość tego, do czego dążą, wśród Ukraińców, szczególnie w przeciwstawieniu do wielkoruskiej anarchii" (Romer, 1995, s. 622-623). Analizując poglądy, jak to określił, quasi-inteligencji białoruskiej, zauważał, że wśród niej „mało jest świadomości odrębności białoruskiej i nie ma żadnego programu politycznego" (Romer, 1995, s. 622-623). Wskazywał, że jego rozmówcom nie towarzyszyło pytanie o suweren-

2 Glinka, używając nazwy Związek Włościański, miał zapewne na myśli odbyty w Mińsku w kwietniu 1917 r. pierwszy Zjazd Delegatów Chłopskich.

3 Autor miał zapewne na myśli I Zjazd Wszechbiałoruski, który obradował w Mińsku w grudniu 1917 r. W jego pracach wzięli udział - obok przedstawicieli wymienionych wyżej guberni - także reprezentanci guberni smoleńskiej i grodzieńskiej. 
ność Białorusi, ale obawy o to, czy zostanie ona przyłączona do Polski lub Litwy oraz „czy Niemcy zechcą zabierać kraj tak biedny i mało ponętny” (Romer, 1995, s. 623).

Korwin-Kossakowski konstatował natomiast w listopadzie 1917 r., że do przekonania Białorusinów trafiało bardziej żywotne, ,zrozumiałe, [...] hasło «walki z panami»" niż budowanie białoruskiej państwowości, której idea była niezrozumiała dla „tutejszych «człowików»” (2016a, s. 291). Nie omieszkał też zauważyć, że prawdopodobne dla Białorusinów, a niezwykle groźne dla właścicieli ziemskich, mogło się stać rozwiązanie, które zapowiadał, ogłoszony przez Ukraińską Centralną Radę 7/20 listopada 1917 r., III Uniwersat zawierający zapowiedź nacjonalizacji ziemi (Kossakowski, 2016a, s. 291).

Dodajmy, że Korwin-Kossakowski zamieszczał w diariuszu lapidarne informacje o białoruskich aspiracjach, uznając, że Białorusini powiążą ogłoszenie niepodległości z zapowiedzią pozbawienia Polaków mienia (tak jak na Ukrainie). Pisał, że mieli oni wychodzić z założenia, iż „hasło walki z panami zespoli wolnych obywateli, a wtedy podsunąć im niepodległość jako odmianę bezkarnej grabieży polskich pomieszczików nie będzie trudno" (Kossakowski, 2016a, s. 305-306). Nie umknęła również autorowi diariusza wzrastająca aktywność Białorusinów w tej materii, która wyrażała się w przygotowaniu przez Wielką Radę Białoruską ${ }^{4}$ (Rada Białoruska) stosownych dekretów czy chociażby odezwy będącej „niewolniczą kopią uniwersału ukraińskiego”. Twierdził, że krzewiła ona nienawiść do Polaków, a jej autorem miał być redaktor „Minskogo Gołosa” Skrynczenko (Kossakowski, 2016a, s. 293, 305-306, 350).

Warto zauważyć, że Korwin-Kossakowski krytycznie oceniał przygotowanie białoruskich działaczy narodowych do organizowania, jak to określił, „życia państwowego" w sytuacji, gdy Mińsk i ziemie białoruskie okupowane były przez Niemców. Dowodził, że wśród polskich polityków panowało przekonanie (po rozmowach z przedstawicielami niemieckiej władzy w stolicy Białorusi), że „Rada Białoruska” zostanie przez Niemców rozwiązana, ponieważ nie wierzyli oni $w$,jej zdolność do pracy i w żywotność, mają zamiar atoli liczyć się z każdym miejscowym samorządem, o ile wyrażać będzie rzeczywiście interesy ogólne ludności i posiadać zdolność do pracy" (Kossakowski, 2016b, s. 130).

Reasumując, należy zauważyć, że Białoruś i jej mieszkańcy stanowili przedmiot zainteresowań autorów wspomnień. Jednakże panujące tam stosunki, poziom życia itp. nie były kwestiami, którym poświęcali większą uwagę. Niemniej jednak obserwacje poczynione tak przez miejscowych, jak i przybyłych do guberni białoruskich polskich memuarystów niewątpliwie posiadają walor poznawczy. Szczególnie wartościowe są wówczas, gdy dla piszącego pobyt w wymienionych guberniach oznaczał

4 Wielka Rada Białoruska została powołana podczas odbywającego się w Mińsku w październiku 1917 r. (st. st.) zjazdu Białoruskiej Socjalistycznej Hromady i miała reprezentować białoruskie demokratyczne ugrupowania i partie polityczne.

5 M.S. Korwin-Kossakowski, używając w diariuszu tego sformułowania w zapisie datowanym na 24 II 1918 r., prawdopodobnie miał na myśli Komitet Wykonawczy Rady I Zjazdu Wszechbiałoruskiego, który później przekształcił się w Radę Białoruskiej Republiki Ludowej. 
zetknięcie z nieznanymi wcześniej realiami. Pozwalają bowiem zapoznać się z opisami wsi, miasteczek i miast, charakterystyką miejscowej ludności, a zarazem oceną aspiracji politycznych Białorusinów w tak szczególnym okresie, jakim była I wojna światowa.

\section{Bibliografia}

Czapska, Maria. (2004). Europa w rodzinie. Czas odmieniony. Kraków: Wydawnictwo Znak.

Glinka, Władysław. (1927). Pamiętnik z Wielkiej Wojny. T. 1-4. Warszawa: Skład Główny Gebethner i Wolff.

Kieniewicz, Antoni. (1989). Nad Prypecia, dawno temu... Wspomnienia zamierzchłej przeszłości. Wrocław-Warszawa-Kraków: Zakład Narodowy im. Ossolińskich.

Kossakowski, Michał, Stanisław. (2010). Diariusz 21 V-31 VIII 1915. Marek Mądzik (red.). T. 1. Cz. 1. Lublin: Wydawnictwo UMCS.

Kossakowski, Michał, Stanisław. (2016a). Diariusz 29 kwietnia-31 grudnia 1917. Dariusz Tarasiuk, Mariusz Korzeniowski, Krzysztof Latawiec (red.). T. 2. Lublin: Wydawnictwo UMCS.

Kossakowski, Michał, Stanisław. (2016b). Diariusz 1 stycznia-31 grudnia 1918. Mariusz Korzeniowski, Dariusz Tarasiuk, Krzysztof Latawiec (red.). T. 3. Lublin: Wydawnictwo UMCS.

Obiezierska, Helena. (1995). Jedno życie prywatne na tle życia narodu polskiego $w$ wieku XX. Bydgoszcz: Wydawnictwo TANAN.

Romer, Eugeniusz. (1995). Dziennik 1914-1918. Warszawa: Wydawnictwo Interlibro.

Wojciechowski, Stanisław. (1938). Moje wspomnienia. T. 1. Lwów: Książnica-Atlas.

Woyniłłowicz, Edward. (1931). Wspomnienia 1847-1928. Wilno: Komitet Uczczenia śp. E. Woyniłłowicza.

Wójtowicz, Ryszard, Marian. (1936). Społeczna praca ludowa w czasie wojny. Pamiętnik instruktora opieki nad wygnańcami Centralnego Komitetu Obywatelskiego, pisany na tułaczce w Rosji w latach 1915, 1916, 1917 i 1918. Warszawa: Skład Główny w Domu Książki Polskiej.

Data nadesłania artykułu: 22.08.2018 